\title{
Influence of the structure of Posidonia oceanica meadows modified by bottom trawling on crustacean assemblages: comparison of amphipods and decapods*
}

\author{
P. SÁNCHEZ-JEREZ, C. BARBERÁ-CEBRIAN and A.A. RAMOS-ESPLÁ \\ Unidad de Biología Marina. Dept. Ciencias Ambientales y Recursos Naturales. University of Alicante. Ap.C. 99, \\ 03080 Alicante. Spain. E-mail: psanchez@carn.ua.es
}

\begin{abstract}
SUMMARY: The seagrass Posidonia oceanica plays an important role as habitat for invertebrates. A correlative study was done in El Campello (SE Spain) to understand the relationships between assemblage structure of crustaceans and modification of $P$. oceanica structure caused by bottom trawling. We compared the changes of community structure of the most important groups of crustaceans, amphipods and decapods with changes of cover, density, detritus and rhizome fragments. Sampling was carried out in four control and four impact locations, along a gradient of degradation (17 m depth, August 1992). Multivariate analysis was used for community data (nm-MDS) and P. oceanica structure (PCA). Both groups showed a similar number of species. The amphipod community showed a clear pattern of community changes with significant differences between impact and control locations (global $\mathrm{R}=0.298, \mathrm{p}<0.001$ ) and with significant correlation with $P$. oceani$c a$ structure (global $\rho=0.21, \mathrm{p}<0.05$ ). Detritus (fine and coarse) and rhizome fragments had the highest influence on amphipod distribution. Spatial variability inside of locations was very high. Few species (Dexamine spiniventris, Lysianassa longicornis or Ampelisca spp.) were responsible for disimilarity among locations. Decapods did not show a correlation with the structure of $P$. oceanica. The amphipod community seems to be a strong indicator of the ecological implications of seagrass degradation.
\end{abstract}

Key words: Crustaceans, community structure, habitat complexity, Posidonia oceanica, Mediterranean Sea.

\section{INTRODUCTION}

Mobile invertebrates are distributed in seagrass meadows according to plant attributes. The changes in community structure can be determined by different variables existent in seagrass meadows such as biomass, density, epiphytes or detritus, and the influence that these variables place on each species (Heck and Wetstone, 1977; Stoner, 1980; Lewis, 1984; Stoner and Lewis, 1985; Howard et al., 1989; Edgar, 1990; Berggren, 1993; Harlin et al., 1996). Many manipulative and correlative studies have

*Received June 21, 1999. Accepted March 6, 2000. been developed during the last decades to better understand the processes which influence the relationships between spatial distribution of invertebrates and habitat structure (Fonseca et al., 1990; Edgar, 1990; Schneider and Mann, 1991). However invertebrate-seagrass relationships in the Posidonia oceanica system are not well known.

Along the Mediterranean coast Posidonia oceanica develops meadows in shallow sandy bottoms (Buia and Mazzella, 1991), and is an important habitat for mobile invertebrates (Mazzella et al., 1989). Extensive degradation of Posidonia oceanica meadows due to bottom trawling has occurred in SouthEast Spain. The impact of trawling on $P$. oceanica 
produces a reduction of canopy cover and an increase of detritus by erosion, which has an important influence on the invertebrate community (Sánchez Jerez and Ramos Esplá, 1996).

Among the invertebrates associated with seagrass meadows, crustaceans are the most important group, comprising a large number of species with substantial abundance and biomass, as well as being extraordinarily important as a trophic resource for fish populations (Bell and Harmelin, 1983; Edgar and Shaw, 1995a, b). To understand the effects of environmental impacts on the seagrass system it is very important to characterise the changes of crustacean assemblages due to the alteration of habitat features. Amphipods and decapods are the most abundant crustaceans in association with $P$. oceanica meadows (Mazzella et al., 1989; García-Raso, 1990; Scipione and Chessa, 1993; Sánchez Jerez, 1997). Therefore, these groups should be affected by meadow modification, which concurrently affects the ecological processes of the overall community (Virnstein, 1987). However, depending on their different life history, these two groups can be influenced in different ways (Warwick and Clarke, 1991; Sánchez Jerez and Ramos Esplá, 1996).

For this study we were interested in testing two questions: (i) Which parameters of the meadow structure have the most influence on crustaceans, especially the decapod and amphipod communities? and (ii) Will these two groups, with different life histories, model similar patterns of response? A field experiment comparing decapod and amphipod community structures in several sites along a gradient of degraded (due to bottom trawling) P. oceani$c a$ meadow was designed to research the relationship between seagrass structure and crustacean assemblages.

\section{MATERIAL AND METHODS}

The study was carried out in August 1992 on the P. oceanica meadow of El Campello (Alicante, SE Spain), which was modified by bottom trawling into a gradient of degradation. In south-east Spain, a majority of the soft bottom with a range of 5 to $23 \mathrm{~m}$ in depth is continuously covered by seagrass for tens of kilometres, with occasional patches of sand and Cymodocea nodosa meadows. It is estimated that $40 \%$ of P. oceanica in El Campello has been degraded by illegal bottom trawling (Sánchez Lizaso et al., 1990) (Fig. 1). Nearly 200 trawlers fish around the

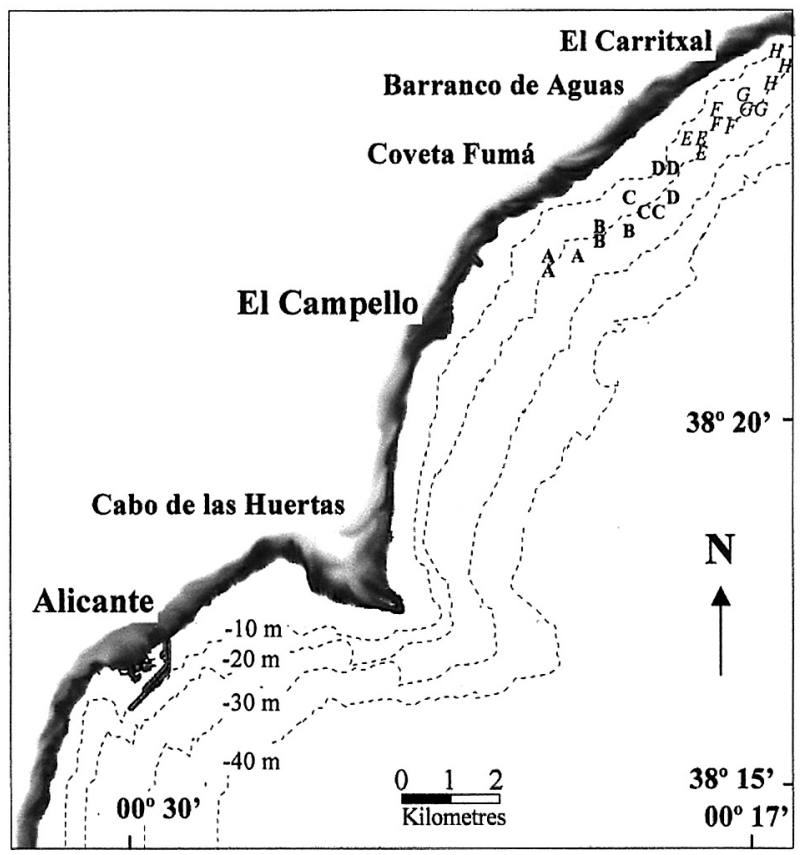

FIG. 1. - Geographical location of sampling sites. Sites A-D were in relatively non-impacted meadows, and sites E-H were on trawled meadows, at $17 \mathrm{~m}$ depth.

study area and it is a common practice to trawl in shallow bottoms, over seagrass meadow usually operating under cover of darkness, though it is illegal (at present the area is protected by an antitrawling artificial reef; Ramos Esplá et al., 1999).

Based on preliminary studies (Sánchez Lizaso et al., 1990; Ramos Esplá et al., 1991) and personal prospecting, eight locations were selected along the El Campello coast at $17 \mathrm{~m}$ depth. At this depth the meadow was only partially degraded. The location selection was supported by the number of loose rhizomes on the bottom and the existence of gear erosion (long bands of dead meadow around $40 \mathrm{~cm}$ wide), covering a gradient of degradation from degraded meadow to pristine meadow. Control sites did not show any signs of direct erosion. Four locations (A-D) were in relatively pristine meadow (around $80 \%$ cover) and another four (E-H) in degraded meadow (around 65\% cover). We randomly choose three sites inside of each location to avoid spatial pseudo-replication. Also to avoid temporal dependence of data, the sites were sampled randomly along the sampling time.

In each site, three random samples of $0.125 \mathrm{~m}^{2}$ of the meadow were taken during the day, using a suction device (500 $\mu \mathrm{m}$ mesh size; Brook, 1979). This sampling method has been used by many authors with adequate results (e.g. decapods, Vadon, 1981; epifauna, Francour, 1990). The samples were taken 
at the same time by scuba-diving. Shoot density inside the quadrants was measured after taking the samples. At the laboratory, amphipods and decapods were sorted and identified to species level. Detritus was sieved into two fractions: fine (1 to $8 \mathrm{~mm}$ ), and coarse $(>8 \mathrm{~mm})$. Fragments of dried rhizomes were also sorted. Detritus and rhizome fragments were dried in a dessicator for $24 \mathrm{~h}$ at $80^{\circ} \mathrm{C}$ (Romero et al., 1992) and weighed.

Data on amphipod and decapod abundance was analysed by non-parametric multidimensional scaling (MDS) using PRIMER software (Plymouth Laboratory; Warwick and Clarke, 1993; Clarke and Warwick, 1994). The similarity matrix among samples was calculated by using the Bray-Curtis similarity index with a double square transformation of the data. It was used to construct bi-variate plots of MDS and to calculate a permutation test of significance (analysis of similarities, ANOSIM). Using SIMPER (similarities percentage), the percentage of influence of each species on the Bray-Curtis matrix values was calculated (Clarke, 1993).

The Spearman's rank correlation coefficient was calculated to establish the correlation between the $P$. oceanica structure and community attributes, using RELATE (PRIMER; Clarke and Warwick, 1994). The similarity matrix of seagrass variables was calculated by Euclidean distances, using standardised data (Clarke and Warwick, 1994). To outline the optimal set of seagrass features that best explains the community structure we followed the BIO-ENV procedure defined by Clarke and Ainsworth (1993). Seagrass variables were analysed, as a whole, using a correlation-based principal components analysis (PCA). A lower triangular Euclidean distance matrix relating to the analyses was constructed (Clarke and Green, 1988). A graphical representation of the changes in $P$. oceanica structure was compared with fauna attributes (Clarke and Warwick, 1994). Additionally statistical differences of Posidonia features between impact and control sites were estimated by analysis of variance.

\section{RESULTS}

\section{Community structure}

Decapods were the best represented order, with a total of 34 species: 24 in the impacted sites and 29 in the control sites (Table 1). The community was dominated by Thoralus cranchii (Leanch, 1817),

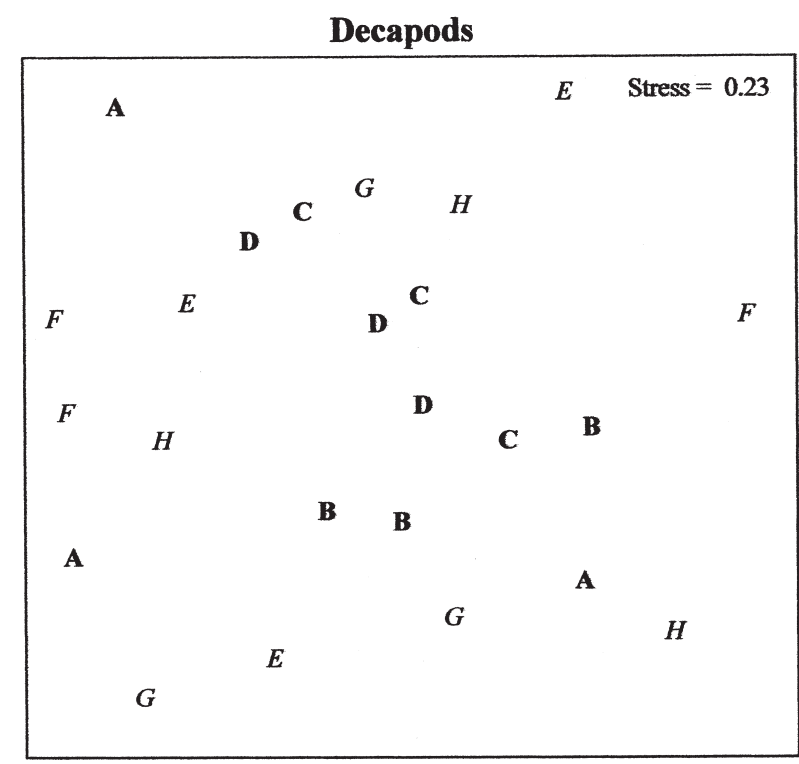

FIG. 2. - MDS bi-dimensional representation of decapod assemblages. A-D, control sites; E-H, impact sites.

Achaeus gracilis Costa, 1839 and Athanas nitescens (Leach, 1814). The amphipods had a species richness similar to that of the decapods ( 32 species): 22 species in the impacted site and 29 in the control sites. Ampelisca spp Kroyer, 1842, Dexamine spinosa (Montagu, 1813), Maera knudseni Reid, 1951 and Lysianassa longicornis Lucas, 1849 were the most abundant species (Table 1).

The MDS representation based on the decapod community displayed a scattered plot of sites without a pattern of aggregation related to degraded or control sites (Fig. 2), with a stress value of 0.23 which is relatively high. However, the bi-dimensional representation of amphipod MDS showed a certain segregation of sites from the control meadow (A-D) in comparison to sites of the impacted meadow $(\mathrm{E}-\mathrm{H})$, but also with a relatively high value of stress (Fig. 3). Also, the spatial heterogeneity among sites was very high, mainly among the control sites. It is important to remark that the interpretation of MDS should be done carefully because of the high values of stress.

The pattern observed in the amphipod community was consistently demonstrated by ANOSIM. This permutation test showed significant differences between control and impact sites with respect to amphipod community structure (global $\mathrm{R}=0.298$, $\mathrm{p}<0.001)$. Decapods did not show statistical differences (global $\mathrm{R}=0.003$, non significant). The amphipod species which had a higher influence on the dissimilarities among control and impact sites (SIM- 
TABLE 1. - Average abundance of decapods and amphipods (ind. $\mathrm{m}^{-2} \pm \mathrm{SE}$ ) by sampling site: A-D, control sites; E-H, impact sites. Ratio shows the contribution of the most important species in the dissimilarities between control and impact sites after SIMPER.

\begin{tabular}{|c|c|c|c|}
\hline & Ratio & A-D & $\mathrm{E}-\mathrm{H}$ \\
\hline \multicolumn{4}{|l|}{ Decapoda } \\
\hline Hippolyte inermis (Leach, 1815) & 1.04 & $11.3 \pm 3.3$ & $4.7 \pm 2.5$ \\
\hline H. leptocerus (Heller, 1863) & & $0.6 \pm 0.6$ & - \\
\hline Thoralus cranchii (Leach, 1817) & 1.15 & $35.3 \pm 9.9$ & $18.0 \pm 7.3$ \\
\hline Alpheus macrocheles (Hailstone, 1835) & & $0.6 \pm 0.6$ & - \\
\hline Athanas nitescens (Leach, 1814) & 1.11 & $10.0 \pm 3.0$ & $15.3 \pm 7.1$ \\
\hline Processa modica Will. and Roch., 1979 & 1.12 & $13.3 \pm 3.7$ & $8.7 \pm 4.2$ \\
\hline Periclimenes scriptus (Risso, 1822) & & $1.3 \pm 0.9$ & $2.0 \pm 1.4$ \\
\hline Calcinus tubularis (Roux, 1830) & & $0.6 \pm 0.6$ & $0.6 \pm 0.6$ \\
\hline Cestopagurus timidus (Roux, 1830) & & $0.6 \pm 0.6$ & $0.6 \pm 0.6$ \\
\hline Diogenes pugilator (Roux, 1829) & & $2.0 \pm 2.0$ & - \\
\hline Paguristes eremita (Linnaeus, 1818) & & - & $0.6 \pm 0.6$ \\
\hline Pagurus cuanensis Bell, 1846 & 0.96 & $0.6 \pm 0.6$ & $3.3 \pm 1.2$ \\
\hline$P$. anachoretus Risso, 1827 & & $1.3 \pm 0.9$ & $1.3 \pm 0.9$ \\
\hline P. chevreuxii (Bouvier, 1896) & & - & $0.6 \pm 0.6$ \\
\hline Anapagurus curvidactylus Chev. and Bour. 1892 & & - & $2.0 \pm 2.0$ \\
\hline Galathea bolivari Zariquiey-Alvarez, 1968) & & $4.0 \pm 2.3$ & $2.6 \pm 1.1$ \\
\hline Pisidia longicornis (Linnaeus, 1767) & & $3.3 \pm 1.5$ & - \\
\hline P. longimana (Risso, 1816$)$ & & $2.0 \pm 1.4$ & - \\
\hline Dromia personata (Linnaeus, 1759) & & $0.6 \pm 0.6$ & - \\
\hline Ethusa mascarone (Herbst, 1785) & & $2.0 \pm 1.4$ & $0.6 \pm 0.6$ \\
\hline Ilia nucleus (Linnaeus, 1758) & & $0.6 \pm 0.6$ & - \\
\hline Ebalia edwardsi Costa, 1838 & 1.07 & $8.0 \pm 3.7$ & $8.7 \pm 2.3$ \\
\hline Sirpus zariquieyi Gordon, 1953 & 0.89 & $4.0 \pm 1.5$ & $3.3 \pm 1.54$ \\
\hline Liocarcinus arcuatus (Leach, 1814) & & $0.6 \pm 0.6$ & $2.0 \pm 1.43$ \\
\hline Eurynome aspera (Pennant, 1777) & & $1.3 \pm 0.9$ & $1.3 \pm 0.9$ \\
\hline E. spinosa Hailstone, 1835 & 1.05 & $8.0 \pm 2.6$ & $2.6 \pm 1.5$ \\
\hline Achaeus gracilis Costa, 1839 & 0.96 & $16.0 \pm 3.3$ & $15.3 \pm 4.6$ \\
\hline Macropodia rostrata (Linnaeus, 1761) & & $0.6 \pm 0.6$ & $2.0 \pm 1.0$ \\
\hline M. czerniavskii Forest and Zariquiey, 1964 & & $2.6 \pm 2.6$ & $0.6 \pm 0.6$ \\
\hline Inachus phalagium Fabricius, 1775 & & $2.6 \pm 1.1$ & $3.3 \pm 2.7$ \\
\hline Pisa armata (Latreille, 1803) & & $1.3 \pm 0.9$ & - \\
\hline Maja crispata Risso, 1827 & & $0.6 \pm 0.6$ & - \\
\hline Total density decapods & & $135 \pm 27.1$ & $102.0 \pm 18.4$ \\
\hline Species richness & & 29 & 24 \\
\hline \multicolumn{4}{|l|}{ Amphipoda } \\
\hline Iphimedia minuta Sars, 1882 & 0.88 & $2.7 \pm 2.0$ & $4.0 \pm 1.6$ \\
\hline Ampelisca spp. Kroyer, 1842 & 1.21 & $2.7 \pm 2.0$ & $11.3 \pm 3.9$ \\
\hline Amphithoe ramondi Audouin, 1826 & 0.8 & $1.3 \pm 1.3$ & $4.7 \pm 2.1$ \\
\hline Cymadusa crassicornis (Costa, 1857) & & $2.0 \pm 1.4$ & $5.3 \pm 3.3$ \\
\hline Aora spinicornis Afonso, 1976 & 1.12 & $5.3 \pm 4.2$ & $12.0 \pm 4.1$ \\
\hline Leptocheirus guttatus (Grube, 1864) & & $0.7 \pm 0.7$ & $1.3 \pm 0.9$ \\
\hline Apherusa chiereguinii Giordani-Soika, 1950 & 0.83 & $22.6 \pm 5.8$ & $0.7 \pm 0.7$ \\
\hline A. vexatrix Krapp-Schickel, 1979 & 0.91 & $5.3 \pm 1.8$ & $1.3 \pm 0.9$ \\
\hline Corophium minimum Schiecke, 1979 & & $0.7 \pm 0.7$ & - \\
\hline Siphonocetes spp. Kroyer, 1845 & 1.01 & $22.6 \pm 5.8$ & $5.3 \pm 0.6$ \\
\hline Atylus guttatus (Costa, 1851) & & $1.3 \pm 1.3$ & - \\
\hline A. vedlomensis (Bates and Westwood, 1862) & 1.05 & $5.3 \pm 2.0$ & $9.3 \pm 2.4$ \\
\hline Dexamine spiniventris (Costa, 1853) & 1.12 & $4.7 \pm 1.5$ & $13.3 \pm 3.9$ \\
\hline D. spinosa (Montagu, 1813) & 1.04 & $2.0 \pm 1.4$ & $8.0 \pm 2.4$ \\
\hline Eusiroides dellavalei Chevreux, 1899 & 0.91 & $4.0 \pm 1.2$ & - \\
\hline Ceradocus semiserratus (Bate, 1862) & & $0.7 \pm 0.7$ & - \\
\hline Elasmopus rapax Costa, 1853 & & $0.7 \pm 0.7$ & - \\
\hline Gammarella fucicola Leach, 1814 & & $1.3 \pm 0.9$ & $0.7 \pm 0.7$ \\
\hline Maera grossimana (Montagu, 1808) & & $2.0 \pm 1.4$ & $1.3 \pm 0.9$ \\
\hline M. knudseni Reid, 1951 & 1.01 & $2.0 \pm 1.4$ & $12.7 \pm 5.2$ \\
\hline Leucothoe spinicarpa (Abildgaard, 1789) & & $2.0 \pm 2.0$ & $0.7 \pm 0.7$ \\
\hline Lepidepecreum longicorne (Bate andWestwood, 1861) & & $0.7 \pm 0.7$ & -10.0 \\
\hline Lysianassa longicornis Lucas, 1849 & 1.18 & $12.0 \pm 3.3$ & $1.3 \pm 1.3$ \\
\hline L. pilicornis Heller, 1866 & & - & $1.3 \pm 0.9$ \\
\hline Orchomene humilis (Costa, 1853) & & $2.0 \pm 1.4$ & $0.7 \pm 0.7$ \\
\hline Monoculodes carinatus (Bate, 1857) & & $0.7 \pm 0.7$ & - \\
\hline Pereinotus testudo (Montagu, 1808) & & $0.7 \pm 0.7$ & - \\
\hline Hyale stebbingi Chevreux, 1888 & & $2.0 \pm 2.0$ & - \\
\hline Caprella acanthifera Leach, 1814 & & $0.7 \pm 0.7$ & $2.7 \pm 1.1$ \\
\hline Phtisica marina Slabber, 1769 & & $2.0 \pm 1.0$ & $1.3 \pm 0.9$ \\
\hline Pseudoprotella phasma (Montagu, 1804) & & - & $0.7 \pm 0.7$ \\
\hline Total density amphipods & & $96.9 \pm 19.8$ & $114.0 \pm 12.3$ \\
\hline Species richness & & 29 & 22 \\
\hline
\end{tabular}




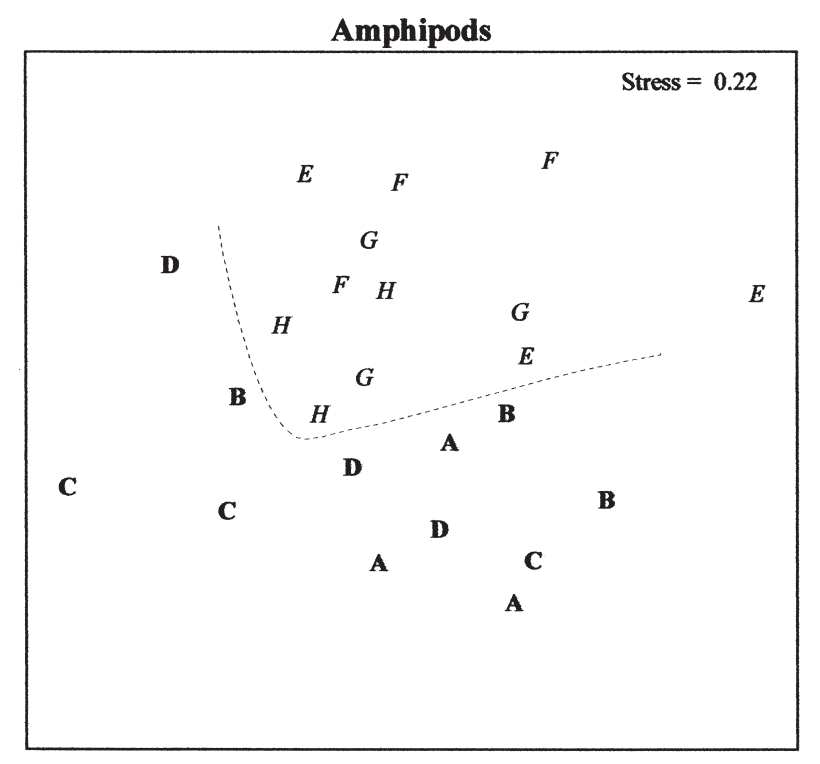

FIG. 3. - MDS bi-dimensional representation of amphipod assemblages. A-D, control sites; E-H, impact sites.

PER, average dissimilarity of $71.12 \%$ ) were Maera knudseni (ratio 1.01), Lysianassa longicornis (ratio 1.18), Ampelisca spp. (ratio 1.21), Siphonocetes spp. (ratio 1.01), Aora spinicornis (ratio 1.12) and Dexamine spiniventris (ratio 1.12). The decapod assemblage produced only a $58.39 \%$ dissimilarity between control and impact sites. The most important species were Thoralus cranchii (ratio 1.15), Processa modica (ratio 1.12), Hippolyte spp. (ratio 1.04), Ebalia edwardsi (ratio 1.07), Athanas nitescens (ratio 1.11) and Eurynome spinosa (ratio 1.05).

\section{Relationship with $P$. oceanica features}

Density, cover and detritus characteristics of the P. oceanica meadows studied are shown in Table 2. Density was very similar among the sites, but showed significant differences $(p<0.05)$. The cover was reduced by around a $20 \%$ at the impact sites

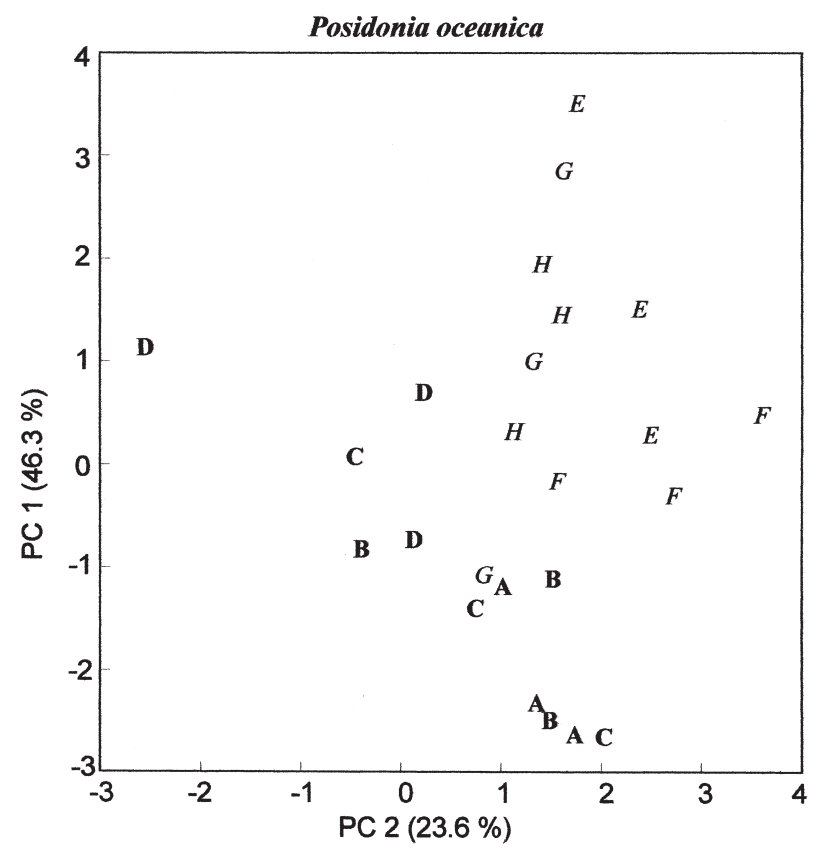

FIG. 4. - PCA bi-dimensional representation of $P$. oceanica structure. A-D, control sites; E-H, impact sites. $\mathrm{PC} 1=46.3 \%$ and $\mathrm{PC} 2=23.6 \%$

$(\mathrm{p}<0.01)$. Fine and coarse detritus were more abundant at the impact sites $\left(5.08\right.$ and $\left.4.42 \mathrm{gdw} / \mathrm{m}^{2}\right)$, showing significant differences. The fragments of rhizomes were a more variable feature among sites, with an average of 6.68 and $4.54 \mathrm{gdw} / \mathrm{m}^{2}$ in control and impact sites, respectively, without showing significant differences (Table 2).

The ordination of PCA based on the overall $P$. oceanica features revealed the existence of clear differences among the different sampling sites, except for an impact site $(\mathrm{G})$ which was distributed among the control sites (Fig. 4). The PC1 axis explains $46.3 \%$ of variation and the $\mathrm{PC} 2$ axis $23.6 \%$ of variation. By comparing Figures 3 and 4 it is possible to identify a similar pattern between the amphipod MDS and P. oceanica PCA.

TABLE 2. - Density of Posidonia oceanica (shoots per $\mathrm{m}^{2}$ ), cover $(\%)$ and detritus (grams dry weight per $\mathrm{m}^{2}$ ) values for the sampling locations.

\begin{tabular}{|c|c|c|c|c|c|}
\hline Sampling locations & Density & Cover & Fine detritus & Coarse detritus & Fragmented rizhomes \\
\hline A & $25.6 \pm 2.8$ & $0.90 \pm 0.03$ & $2.39 \pm 0.96$ & $0.81 \pm 0.02$ & $1.55 \pm 0.51$ \\
\hline B & $23.3 \pm 1.4$ & $0.87 \pm 0.04$ & $2.72 \pm 0.57$ & $1.50 \pm 0.48$ & $5.97 \pm 3.77$ \\
\hline $\mathrm{C}$ & $22.3 \pm 6.2$ & $0.85 \pm 0.06$ & $2.27 \pm 1.06$ & $1.91 \pm 0.88$ & $7.66 \pm 2.70$ \\
\hline $\mathrm{D}$ & $26.6 \pm 3.8$ & $0.85 \pm 0.04$ & $5.85 \pm 0.78$ & $3.34 \pm 0.68$ & $11.55 \pm 3.47$ \\
\hline Average (A-D) & $24.5 \pm 1.7$ & $0.87 \pm 0.02$ & $3.31 \pm 0.58$ & $1.89 \pm 0.38$ & $6.68 \pm 1.64$ \\
\hline$E$ & $21.6 \pm 0.6$ & $0.61 \pm 0.05$ & $5.95 \pm 1.12$ & $5.84 \pm 1.96$ & $2.87 \pm 1.26$ \\
\hline$F$ & $19.7 \pm 3.9$ & $0.64 \pm 0.06$ & $3.78 \pm 0.48$ & $2.54 \pm 0.49$ & $2.22 \pm 0.08$ \\
\hline$G$ & $22.3 \pm 1.3$ & $0.70 \pm 0.06$ & $4.91 \pm 1.87$ & $4.85 \pm 1.26$ & $6.23 \pm 0.55$ \\
\hline$H$ & $21.3 \pm 4.9$ & $0.65 \pm 0.05$ & $5.65 \pm 0.67$ & $4.44 \pm 1.22$ & $6.82 \pm 1.15$ \\
\hline Average (E-H) & $21.2 \pm 1.4$ & $0.65 \pm 0.02$ & $5.08 \pm 0.56$ & $4.42 \pm 0.67$ & $4.54 \pm 0.71$ \\
\hline
\end{tabular}


Using RELATE, we confirmed this similar pattern between seagrass features and amphipod community, showing a significant value for the Spearman's rank correlation coefficient (global $\rho=0.21$, $\mathrm{p}<0.05$ ). Decapod community structure did not show significant correlation with seagrass features (global $\rho=-0.05$, not significant). BIO-ENV indicated that the features which better explain the amphipod distribution in P. oceanica meadows were detritus abundance (fine and coarse) and rhizomes fragments.

\section{DISCUSSION}

In the present study amphipod and decapod species were typically representative of $P$. oceanica community (García-Raso, 1990; Scipione, 1992). The crustacean communities showed different response to seagrass structure. Amphipod assemblages seem to be structured by the physical characteristics of $P$. oceanica meadows such as the remains of vegetal fragments. However biological relationship such as predation can also play an important role in structuring the communities (Martin-Smith, 1993). Decapods did not show any correlation with meadow structure. In both cases, the number of species was very similar between control and impact sites.

Degradation by bottom trawling changes the structure of $P$. oceanica seagrass, reducing density and cover, and increasing detritus compartment. The analysis of the overall structure of $P$. oceanica meadows showed the existence of a clear spatial gradient, which modified the habitat structure available to invertebrates. Variation in structural complexity may well be produced by other environmental factors, but human activities, such as trawling, play a very important role in the SE of the Iberian Peninsula because of the intensity of this impact (Sánchez Lizaso et al., 1990).

Several studies have been conducted on amphipods associated with $P$. oceanica (Scipione and Fresi, 1984; Mazzella et al, 1989; Mazzella et al, 1992; Scipione, 1992; Scipione et al., 1996). The amphipod species, which have emphasised the differences among meadows, have certain habitat fidelity. For example, Lysianassa longicornis, Ampelisca spp. and Siphonocetes spp. are related to soft bottoms and commonly associated with $P$. oceanica meadows, and Dexamine spiniventris is associated with leaf stratum (Ruffo, 1982, 1989, 1993; Scipione, 1992; Scipione et al., 1996). The importance of the depth gradient to the distribution of fauna has been stressed (Mazzella et al., 1989). The present study has been carried out at the same depth (17 $\mathrm{m}$ depth) to avoid problems with the fauna change with depth.

The dependence of amphipod structure to the habitat created by seagrass blades near the sediment suggests the importance of complex habitat at this level and the predation pressures during daylight. Amphipod distribution can be correlated to the irregular and patchy distribution of detritus at the same depth, hence also affecting food availability for fish. The importance of seagrass litter to meadow structure has been previously reported. Basically, detritus is valuable both as a food source and for providing protection from predation due to the increase of habitat complexity. Major foods available to small mobile invertebrates within seagrass detritus include various phytoplankton, other invertebrates such as meiofauna, microscopic benthic food such as fungi, bacteria, microalgae, and macroscopic algae, and the detritus themselves (Darnell, 1967).

Direct behavioural observations show that many of these invertebrates appear to be concentrated along the leaf stratum at night when feeding frequencies are highest. For example, peracarids are known to nocturnally climb to and reside in the seagrass canopy while during the day they reside near the bottom (Howard, 1987; Sánchez Jerez et al., 1999 a). If feeding was more selective with regards to dead material and detritus on the sediment, feeding frequencies would tend to show an opposite pattern. Feeding would have been concentrated while animals were on the sediment (Kitting, 1984).

Inversely, decapods did not show a correlation or statistical differences in relation to habitat disturbance. This result coincides with other studies which concluded that decapods do not establish a local population due to their great mobility and larval dispersion, and hence are not useful as community descriptors (Amanieu et al., 1981). Many species of decapods in their postlarval stage are strong swimmers (5-10's of $\mathrm{cm} \mathrm{s}^{-1}$ ), they tend to be fairly long and are capable of swimming appreciable distances. Concurrently the currents over continental shelves have a potential role in the dispersal of decapod adults and larvae (Shanks, 1995). The combination of all of these processes, active and passive transportation, explains the lack of patterns of decapods in function to seagrass environment. Other works confirm this conclusion on large scales. For example, 
density of seagrass shoots in beds was of little importance in determining the abundance of associated decapod assemblages over a large spatial scale in Zostera capricorni meadows, and showed confusing results in Posidonia australis (Worthington et al., 1992). A model to account for variation in distribution and abundance of decapods settling to seagrass from plankton, points out that the abundance of animals among separate beds reflects the supply of larvae to this site (Bell and Westoby, 1986).

Previous attempts to correlate faunal densities within habitat parameters in seagrass meadows have described relationships between some parameters, such as leaf density, biomass, and habitat heterogeneity, with abundances of single species and the overall community structure (Jacobs and Huisman, 1982; Russo, 1989; Edgar, 1992; Edgar and Robertson, 1992; Connolly, 1995; Harlin et al., 1996; Barberá et al., 1997; Sánchez Jerez, et al. 1999 b). Most environmental impact studies focus on communities, because the structure at this level of investigation represents an integration of environmental conditions over a period of time (Warwick, 1993). Research on the amphipod community for detecting the influence of $P$. oceanica modification seem to be a strong indicator of the ecological implications of seagrass degradation, but also the study of single populations such as Dexamine spiniventris, Lysianassa longicornis or Ampelisca spp can be useful.

\section{ACKNOWLEDGEMENTS}

We would like to thank to Dr. Juan Guillén for the identification of decapod species and the colleagues of the Institut d'Ecologia Litoral (El Campello) for sampling assistance. Special thanks to Tara Wilxon for the English translation of the manuscript. Thanks to the anonymous referees for the critical comments and corrections. This work was financed through a Ph.D. scholarship (FP91 21478607) from the Government of Spain (Ministry of Science and Education).

\section{REFERENCES}

Amanieu, M., O. Guelorguet and J. Nouguier-Soule. - 1981. Analyse de la diversité de la macrofauna benthique de una lagune littorale mediterranéene. Vie Milieu, 31(3-4): 303-312.

Barberá Cebrián, C., P. Sánchez Jerez and A.A. Ramos Esplá. 1997. Selección de hábitat en los misidáceos asociados a praderas de fanerógamas marinas. Publ. Espec. Inst. Esp. Oceanogr., 23: 235-242.
Bell, J.D. and M.L. Harmelin-Vivien. - 1983. Fish fauna of French Mediterranean Posidonia oceanica seagrass meadows. 2. Feeding habits. Tethys, 11: 1-14.

Bell J.D. and M. Westoby. - 1986. Abundance of macrofauna in dense seagrass is due to habitat preferences, not predation. Oecologia, 68: 205-209.

Berggren, M. - 1993. Aquaria experiments on habitat choice of littoral shrimps of the Faroe Island. Crustaceana, 65(2): 129-143.

Brook, I. - 1979. A portable suction dredge for quantitative sampling in difficult substrata. Estuaries, 2: 54-58.

Buia, M.C. and L. Mazzella. - 1991. Reproductive phenology of the Mediterranean seagrasses Posidonia oceanica (L.) Delile, Cymodocea nodosa (Ucria) Aschers and Zostera noltii Hornem. Aquat. Bot., 40: 343-362.

Clarke, K.R. - 1993. Non-parametric multivariate analyses of changes in community structure. Aust. J. Ecol., 18: 117-143.

Clarke, K.R. and R.H. Green. - 1988. Statistical design for a 'biological effects' study. Mar. Ecol. Prog. Ser., 46: 213-226.

Clarke, K.R. and M. Ainsworth. - 1993. A method of linking a multivariate community structure to environmental variables. Mar. Ecol. Prog. Ser., 92: 205-219.

Clarke, K.R. and R.M. Warwick. - 1994. Changes in Marine Communities: an approach to statistical analysis and interpretation. Natural Environment Research Council, UK, 144 pp.

Connolly, R.M. - 1995. Effects of removal of seagrass canopy on assemblages of small, motile invertebrates. Mar. Ecol. Prog. Ser., 118: 129-137.

Darnell, R.M. - 1967. Organic detritus in relation to the estuarine ecosystem. In Lauff, G.H. (ed.), Estuaries, pp 376-382. Publ. No. 83, AAAS, Washington, D.C.

Edgar, G.J. - 1990. Population regulation, population dynamics and competition amongst mobile epifauna associated with seagrass. J. Exp. Mar. Biol. Ecol., 144: 205-234.

Edgar, G.J. - 1992. Patterns of colonization of mobile epifauna in a West Australian seagrass bed. J. Exp. Mar. Biol. Ecol., 157: 225-246.

Edgar, G.J. and A.I Robertson. - 1992. The influence of seagrass structure on the distribution and abundance of mobile epifauna: patterns and process in a Western Australian Amphibolis bed. $J$. Exp. Mar. Biol. Ecol., 160: 13-31.

Edgar, G.J. and C. Shaw. - 1995a. The production and trophic ecology of shallow-water fish assemblages in southern Australia. II. Diets of fish and trophic relationships between fish and benthos at Western Port. Victoria. J. Exp. Mar. Biol. Ecol., 194: 83-106.

Edgar, G.J. and C. Shaw. - 1995b. The production and trophic ecology of shallow-water fish assemblages in southern Australia. III General relationships between sediments, seagrasses, invertebrates and fishes. J. Exp. Mar. Biol. Ecol., 194: 107-131.

Fonseca, M.S., W.J. Kenworthy, D.R. Colby, K.A. Rittmaster and G.W. Thayer. - 1990. Comparisons of fauna among natural and transplanted eelgrass Zostera marina meadows: criteria for mitigation. Mar. Ecol. Prog. Ser., 65: 251-265.

Francour, P. - 1990. Dynamique de l'ecosysteme a Posidonia oceanica dans le Parc national de Port-Cross. Analyse des compartiments matte, litiere, fauna vagile, echinodermes et poissons. Ph.D. thesis, Univer. Aix-Marseille II, 373 pp.

García-Raso, J.E. - 1990. Study of crustacea decapoda taxocoenosis of Posidonia oceanica beds from the Southeast of Spain. PSZNI: Mar. Ecol., 11(4): 309-326.

Harlin, M.M., H.M. Rines, C.E. Rose and M.B. Abel. - 1996. Spatial heterogeneity of macrophytes and selected invertebrates in Narragansett Bay (RI, U.S.A.) as revealed by principal component and cluster analysis. Estuar. Coas. Shelf Sci., 42: 123-134.

Heck, K.L.Jr. and G.S. Wetstone. - 1977. Habitat complexity and invertebrate species richness and abundance in tropical seagrass meadows. J. Biogeogr., 4: 23-31.

Howard, R.W. - 1987. Diel variation in the abundance of epifauna associated with seagrasses of the Indian River, Florida, USA. Mar. Biol., 96: 137-142.

Howard, R.K., G.J. Edgar and P.A. Hutchings. - 1989. Faunal assemblage of seagrass beds. In: A.W.D. Larkum, A.J. McComb, and S.A. Shepherd (eds.), Biology of seagrass. A treatise on the biology of seagrasses with special reference to the Australian region, pp. 536-564. Elservier, Amsterdam.

Jacobs, R.P.W.M. and W.H.T. Huisman. - 1982. Macrobenthos of some Zostera beds in the vivinity of Roscoff (France) with special reference to relations with community structure ans environmental factors. In: C. den Hartog (ed.), Proceeding of 
"Component studies in seagrass ecosystems along West European coast”, pp. 97-118.

Kitting, C.L. - 1984. Selectivity by dense populations of small invertebrates foraging among seagrass blade surfaces. Estuaries, 7(4A): 276-288.

Lewis, F.G. - 1984. The distribution of macrobenthic crustaceans associated with Thalassia, Halodule, and bare sand substrata. Mar. Ecol. Prog. Ser., 19: 101-113.

Martin-Smith, K.M. - 1993. Abundance of mobile epifauna: the role of habitat complexity and predation by fishes. J. Exp. Mar. Biol. Ecol., 174: 243-260.

Mazzella, L., M.C. Buia, M.C. Gambi, M. Lorenti, G.F. Russo, M.B. Scipione and V. Zupo. - 1992. Plant-animal trophic relationships in the Posidonia oceanica ecosystems of the Mediterranean Sea: a review. In: D.M. John, S.J. Hawkins and J.H. Price (eds.), Plant-Animal Interactions in the Marine Benthos, pp. 165-187. Oxford: Claredon Press, The Systematics Association.

Mazzella, L., M.B. Scipione and M.C. Buia. - 1989. Spatio-temporal distribution of algal and animal communities in a Posidonia oceanica meadow. P.S.Z.N.I: Mar. Ecol., 10(2): 107-129.

Mazzella, L., M.C. Buia, M.C. Gambi, M. Lorenti, G.F. Russo, M.B. Scipione and V. Zupo. - 1992. Plant-animal trophic relationships in the Posidonia oceanica ecosystems of the Mediterranean Sea: a review. In: D.M. John, S.J. Hawkins, J.H. Price (eds), Plant-Animal Interactions in the Marine Benthos, 165187 pp. Claredon Press, The systematics Association, Oxford.

Ramos Esplá, A.A., L. Martinez, J.L., Sánchez Lizaso, and J.E. Guillén. - 1991. El proyecto de arrecife artificial del Campello (SE Península Ibérica). VII Simp. Iber. Est. Bentos Mar, 146.

Ramos Esplá, A.A., J.E., Guillén, J.T., Bayle, and P. Sánchez Jerez. - 1999. Artificial anti-trawling reef off Alicante, South-Eastern Iberian Peninsula: evolution of reef block and set designs. In: A.C. Jensen, K.J. Collins and A.P.M. Lockwood (eds.): Artificial reefs in European Seas, 195-218 pp. Kluwer Academic Publishers.

Romero, J., G. Pergent, C. Pergent-Martini, M., Mateo and C. Regnier - 1992. The detritic compartiment in a Posidonia oceanica meadow: litter features, descomposition rates and mineral stocks. P.S.Z.N.I: Mar. Ecol., 13(1): 69-83.

Ruffo, S. (ed.). - 1982. The Amphipoda of the Mediterranean. Part 1 Gammaridea (Acanthonotozomatidae to Gammaridae). Mém. Inst. oceanogr. Monaco, 13: 1-364.

Ruffo, S. (ed.). - 1989. The Amphipoda of the Mediterranean. Part 2 Gammaridea (Haustoriidae to Lysianassidae). Mém. Inst. oceanogr. Monaco, 13: 365-576 pp.

Ruffo, S. (ed.). - 1993. The Amphipoda of the Mediterranean. Part 3 Gammaridea (Melphidippidae to Talitridae) Ingolfiellidea, Caprellidea. Mém. Inst. oceanogr. Monaco, 13: 577-813.

Russo, A.R. - 1989. Fluctuations of epiphytal gammaridean amphipods and their seaweed host on an hawaiian algal reef. Crustaceana, 57(1): 23-37.

Sánchez Jerez, P. - 1997. Distribución espacio-temporal de la epifauna vágil asociada a praderas de Posidonia oceanica y Cymodocea nodosa (SE Ibérico). Ph.D. thesis, Uni. Alicante. $217 \mathrm{pp}$.

Sánchez Jerez, P. and A.A. Ramos Esplá. - 1996. Detection of environmental impacts by bottom trawling on Posidonia oceanica (L.) Delile meadows: sensitivity of fish and macroinvertebrate communities. J. Aquat. Ecosys. Health, 5: 239-253.

Sánchez Jerez, P., C. Barberá Cebrián, and A.A. Ramos Esplá. 1999a. Daily vertical migrations in the epifauna associated with Posidonia oceanica meadows. J. mar. biol. Ass. U.K., 79: 971-977.

Sánchez Jerez, P., C. Barberá Cebrián, and A.A. Ramos Esplá. 1999b. Comparison of the epifauna spatial distribution in Posidonia oceanica, Cymodocea nodosa and unvegetated bottoms: Importance of the meadow edges. Acta Oecologica, 20(4): 391405 .

Sánchez Lizaso, J.L, J.E. Guillen, and A.A. Ramos Esplá. - 1990. The regression of Posidonia oceanica meadows in El Campe1lo (Spain). Rapp. Comm. int. Mer Medit., 32,1 , B-I 10:7.

Scipione, M.B. and E. Fresi. - 1984. Distribution of amphipod crustaceans in Posidonia oceanica (L.) Delile foliar stratum. J. Biogeography, 1: 319-329

Scipione, M.B. - 1992. The amphipod population of the Posidonia oceanica leaf stratum around the island of Ischia (Gulf of Naples, Italy). 1st European Crustacean Conference, pp 140. Paris (France).

Scipione, M.B. and L.A. Chessa. - 1993. The benthic fauna of Palau Bay (North-East Sardinia): amphipoda. ICES C.Meeting, B-II(4), 9 .

Scipione, M.B., M.C. Gambi, M. Lorenti, G.F. Russo and V. Zupo. - 1996. Vagile fauna of the leaf stratum of Posidonia oceanica and Cymodocea nodosa in the Mediterranean sea. In: J. Kuo, R.C. Phillips, D.I. Walker, and H. Kirkman (eds.), Seagrass Biology: Proceedings of an International Workshop, pp. 249260. Rottnest Island, Wester Australia.

Schneider, F.I. and K.H. Mann. - 1991. Species specific relationships of invertebrates to vegetation in a seagrass bed. II. Experiments on the importance of macrophyte shape, epiphyte cover and predation. J. Exp. Mar. Biol. Ecol. 145: 119-139.

Shanks, A.L. - 1995. Mechanism of cross-shelf dispersal of larva invertebrates and fishes. In: Mc Edward, L. (ed.) Marine invertebrate larvae, pp. 323-368. CRC Press, Florida.

Stoner, A.W. - 1980. Perception and choice of substratum by epifaunal amphipods associated with seagrasses. Mar. Ecol. Prog. Ser., 3: 105-111.

Stoner, A.W. and F.G. Lewis. - 1985. The influence of quantitative and qualitative aspects of habitat complexity in tropical seagrass meadows. J. Exp. Mar. Biol. Ecol., 94: 19-40.

Vadon, C. 1981 - Les Brachyoures des herbiers de Posidonie dans la region de Villefranche-sur-Mer: biology, écology et variations quantitatives des populations. Ph.D. Thesis. University of Pierre et Marie Curie: 235 pp.

Virnstein, R.W. - 1987. Seagrass-associated invertebrate communities of the Southeastern U.S.A.: a review. Florida Marine Research Publications, 42: 89-116

Warwick, R.M. - 1993. Environmental impact studies on marine communities: pragmatic considerations. Aust. Jour. Ecol., 18: 63-80.

Warwick, R.M. and K.R. Clarke. - 1991. A comparison of some methods for analysing changes in benthic community structure. J. mar. biol. Ass. U.K., 71: 225-244.

Warwick, R.M. and K.R. Clarke. - 1993. Comparing the severity of disturbance: a meta-analysis of marine macrobenthic community data. Mar. Ecol. Prog. Ser., 92: 221-231.

Worthington, D.G., D.J. Ferrell, S.E. McNeill and J.D. Bell. - 1992. Effects of the shoot density of seagrass on fish and decapods evidence of correlation over larger spatial scales? Mar. Biol. 112: 139-146.

Scient. ed.: P. Abelló 